\title{
Enhancement of Technical and Economic Indicators of Power-Generating Units of Thermal Power Plants by Eliminating Flue Gas Recirculation
}

\author{
Taras Kravets $^{a,}{ }^{*}$, Yevhen Miroshnychenko ${ }^{b}$, Andrii Kapustianskyi $^{c}$ \\ ${ }^{a}$ Lviv Polytechnic National University, 12 Stepan Bandera St., Lviv, 79013, Ukraine \\ ${ }^{b}$ National University of Food Technologies, 68 Volodymyrska St., Kyiv, 01033, Ukraine \\ ${ }^{c}$ Techenergo PJSC, 21 Shevchenko Ave., Lviv, 79000, Ukraine
}

Received: March 18, 2021. Revised: April 28, 2021. Accepted: May 05, 2021.

() 2021 The Authors. Published by Lviv Polytechnic National University.

\begin{abstract}
Boiler units at Ukrainian thermal power plants need to be modernized or replaced in the short run, as this is important for the national energy security. The authors determined one of possible ways to improve the efficiency indicators of coal-fired boiler units and power generating units as a whole up to the values exceeding the design ones. This variant of improvement consists in abandoning the technology of using flue gas as drying agent in pulverized coal systems and replacing it with direct discharge of the gas flow into the boiler furnace. Numerous computations were carried out to study the change of efficiency indicators and manoeuvrability of power generating units due to the replacement of the ball mill pulverizing system using flue gases for coal drying with the scheme including ball-andrace mills that use hot air as drying agent.
\end{abstract}

Keywords: manoeuvrability; power generating unit; boiler; pulverized coal system; coal; excess air; energy conversion efficiency.

\section{Introduction}

The ever-present phenomenon on the electrical energy production market in Ukraine is its gradual annual shrinking by 2-5\% due to economic crises, implementation of energy efficiency measures and increase in electricity tariffs for industrial consumers [1]. The share and total volume of thermal coal-fired power generation is also decreasing as new wind and solar farms are built, but it still stays at a level sufficient for ensuring the fulfilment of manoeuvrability criteria of the general power grid. The condition of the equipment of the domestic thermal power plants (TPP), which is beyond its life cycle, does not make it possible to ensure electricity production at competitive prices due to excessive fuel overconsumption for its generation, as compared to any European country, which is the key reason behind the economic stagnation. The ecological guidelines for TPP on coal as the main fuel are getting stricter and stricter [2].

It would be logical to cut down the existing low-efficient heat capacities beyond their life cycle in the course of decarbonisation of the European and Ukrainian economies [3], but, on the other hand, the energy market needs capacities with high manoeuvrability, technical and economic indicators to cover the imbalances of electricity production.

\section{Aim of the research}

In the short run, the only way of improving technical and economic indicators of the existing coal-fired power generating units at TPP is their reconstruction or modernization. Hence, the research aims to develop reconstruction measures for TPP anthracite-fired power generating units with their further conversion to gas coal using low-cost methods, which will also allow extending the fuel range [4].

\footnotetext{
${ }^{*}$ Corresponding author. Email address: taras.y.kravets@1pnu.ua
}

This paper should be cited as: T. Kravets, Y. Miroshnychenko, A. Kapustianskyi. Enhancement of technical and economic indicators of power-generating units of thermal power plants by eliminating flue gas recirculation. Energy Engineering and Control Systems, 2021, Vol. 7, No. 1, pp. 26 - 31. https://doi.org/10.23939/jeecs2021.01.026 


\section{Results and their discussion}

During 2003-2014, reconstructions of TPP power generating units were carried out. However, most measures aimed at maintaining the reliability, i.e. at extending their life cycle, whereas manoeuvrability and economic indicators were left out. Analysis of the reports [5] drives the conclusion that the reconstruction failed to improve the characteristics of lots of boilers; in some cases, even their design values were not achieved. In most cases, the boiler units did not undergo any significant construction changes. The focus was on the restoration and replacement of piping elements and heating surfaces. Some reconstructions were made in the elements of the turbines' flow channels, which resulted in the minimal increase in the installed capacity.

As some parts of the Eastern Ukraine were lost control of, a number of reconstruction measures were implemented to convert the anthracite-fired power generating units to gas flame coal and long flame coal (G and DG grades) [6], [7]. The analysis of the results, methods and ways of implementing these projects [6], [7] showed that such measures do not improve the technical and economic indicators; this is just a change of fuel. As the experimental studies carried out by the co-authors at Prydnistrovska TPP showed, when running such converted power generating units, there are problems with achieving the nominal load. Besides, the efficiency of the turbine drops due to the necessary operation of RH steam injector coolers as the nominal temperature cannot be maintained.

In the world practice, the reference fuel consumption rate in such boiler units is $335-360 \mathrm{~g} / \mathrm{kW} \cdot \mathrm{h}$, while the usual rate for Ukrainian TPPs is $380-430 \mathrm{~g} / \mathrm{kW} \cdot \mathrm{h}$ [1]. The manoeuvrability characteristics of similar power generating units also differ and amount to 50-100\% of the range, whereas in Ukraine the maximum and minimum manoeuvrability are within a more limited range [1].

A detailed comparison of the schematic diagrams of boiler units in most European countries that burn G coal similar to the Ukrainian one with the domestic boiler units' schematic diagrams shows distinct differences in the structure of the pulverized coal systems (Fig. 1, Fig. 2). In Ukraine, pulverized coal systems are based on ball mills with a middle powder bin, whereas the best solution for $\mathrm{G}$ coal is the use of positive-pressure direct-fired systems based on ball-and-race mills.

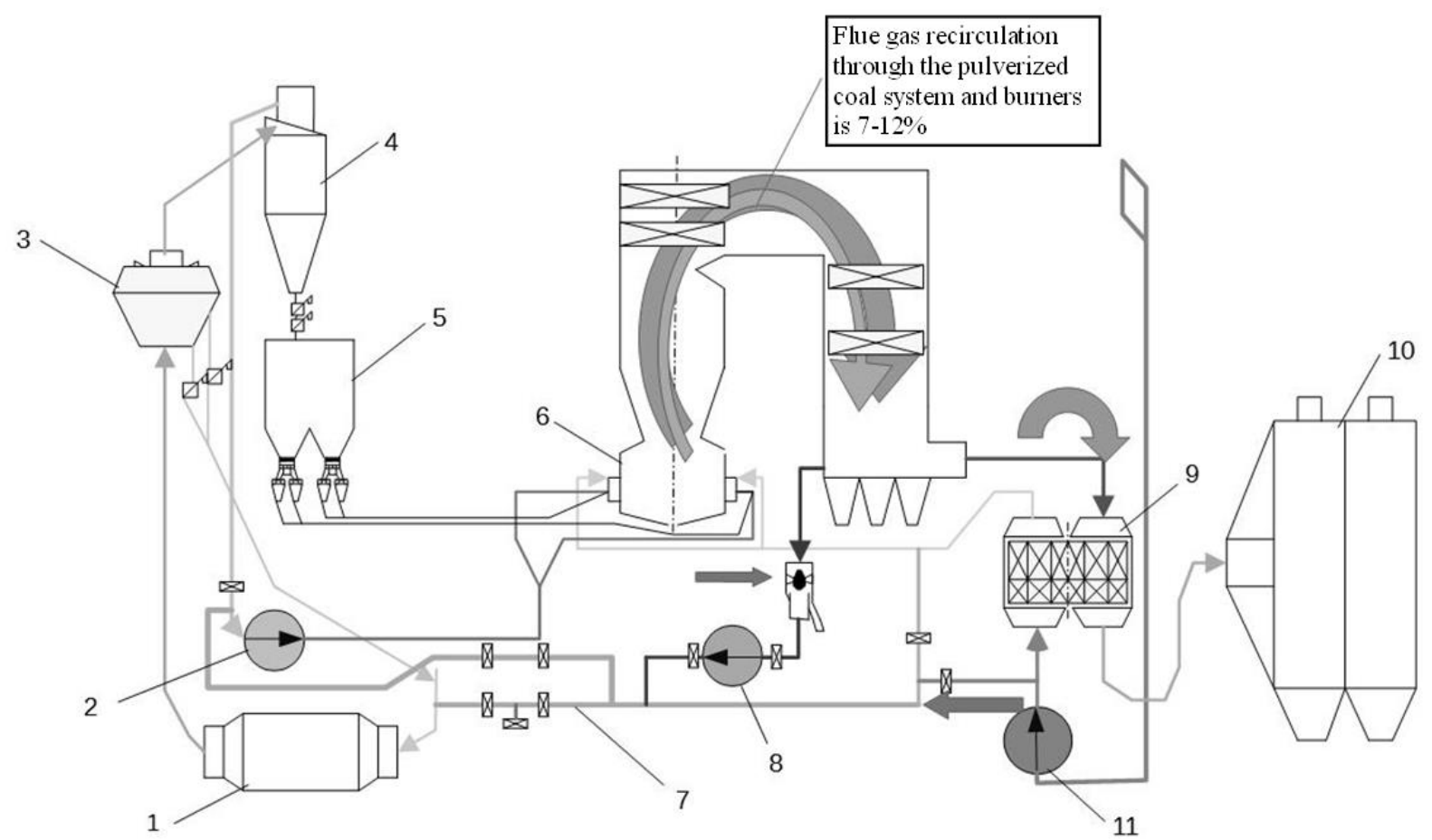

Fig. 1. Schematic diagram of the air-gas flow path of the TPP-210A boiler unit with a ball-mill and a middle powder bin: 1 - ball-mill; 2 - mill fan; 3 - separator; 4 - centrifugal collector; 5 - powder bin;

6 - combustion chamber; 7 - drying agent; 8 - flue gas recirculation fan; 9 - rotary regenerative air heater;

10 - electrical filter; 11 - forced draft fan 


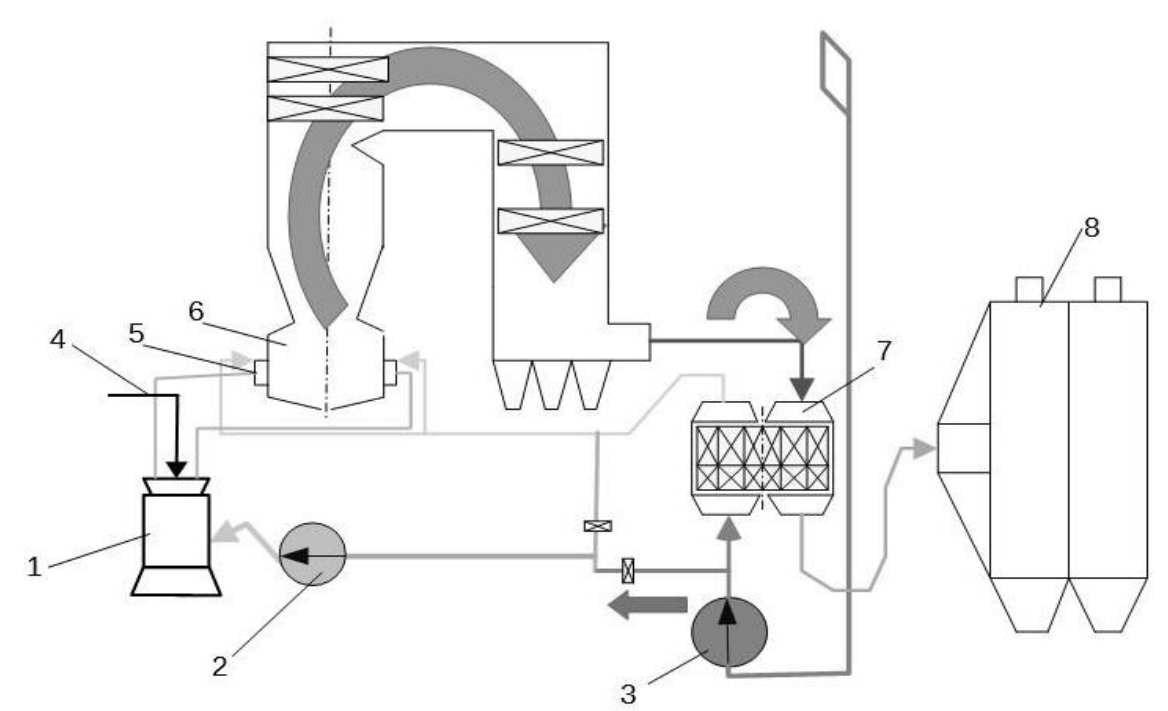

Fig. 2. Schematic diagram of the air-gas flow path of the TPP-210A boiler unit with a positive-pressure direct-fired system: 1 - ball-and-race mill; 2 - mill fan; 3 - forced draft fan; 4 - coal feed;

5 - burners; 6 - furnace; 7 - rotary regenerative air heater; 8 - electrical filter

The regulatory documents [8],[9] provide for possible operation on lean coal of ball-mill pulverisers designed for anthracite and for formally possible use of coal with the content of volatiles over $30 \%$ (i.e., gas coal) with necessary reduction of the air mixture temperature past the mill below $70^{\circ} \mathrm{C}$ and before the burners below $160^{\circ} \mathrm{C}$ by implementing flue gas recirculation. However, such measures affect the boiler efficiency by increasing heat transfer from the furnace into the convective pass, and, as a result, by increasing heat loss with the exhaust gas. Besides, the higher volume of gas (7-12\% for recirculation) causes steam overheating in the convective steam superheaters, and this necessitates enabling emergency injector coolers, the operation of which significantly increases the heat consumption for the production of a kilowatt-hour of electricity (Fig. 3).

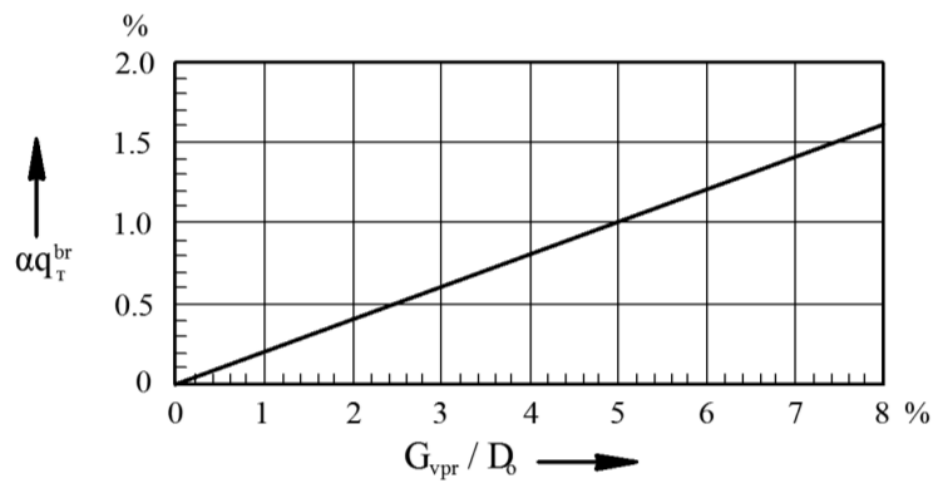

Fig. 3. Correction of heat consumption for electricity production by the K-300-240 turbine [5] for including the injection into the steam superheater

To assess the above-listed factors, the authors used and supplemented the mathematical model described in [10], and developed a computer program in Microsoft Excel on the example of the TPP-210A boiler unit, converted to G grade bituminous coal in the variants of the pulverized coal system with a ball-mill and a middle powder bin and with a positive-pressure direct-fired system based on a ball-and-race mill. The number of infiltrations in the boiler was considered to have increased from the design values to the real operational values [6]. This mathematical model was effectively used by the authors for designing the reconstructions of TPP-210A boilers at st. 1,3,4 at Trypilska TPP and st. 7, 10 at Zmiivska TPP, where the program was verified. The experimental studies of gas coal combustion in TPP-210A boiler units confirmed the results of the implemented modelling (Fig. 4) with an acceptable precision and proved that heat losses with the exhaust gas for cases of positive-pressure direct-fired systems, in contrast to the ballmill cases, decrease and the energy conversion efficiency grows on average by $2.47 \%$. 


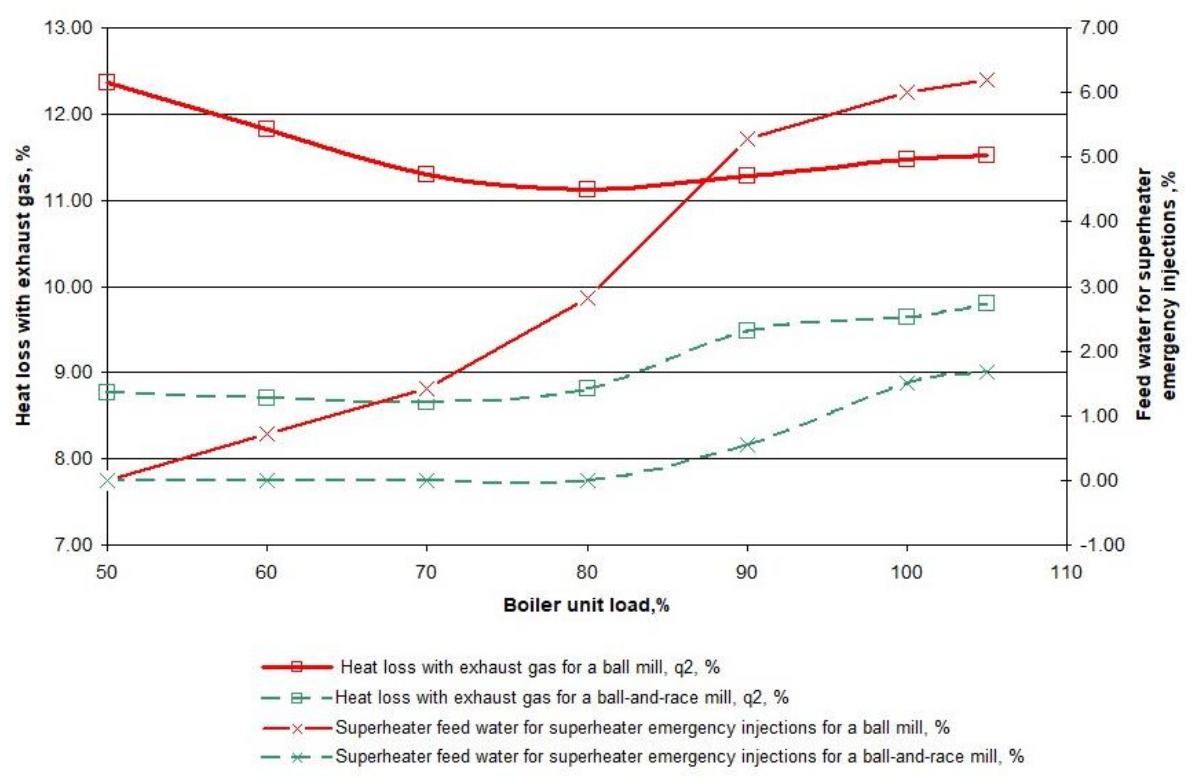

Fig. 4. Analysis of heat loss with exhaust gas and feed-water flow for emergency injections

A significant result is also achieved by stopping the feed water injections in the superheated steam coolers. Using the performance standards for the K-300-240 turbine [11], we can estimate losses caused by enabling the injection system that works practically in the whole operation range for a boiler with a pulverized coal system on a ball mill. In the middle operation range, heat loss on the turbine increases by $0.48 \%$ because of the injection aimed at compensating the steam superheating caused by additional circulation of flue gas to ensure safe operation of pulverized coal systems with a ball mill (Fig. 3).

In order to study the manoeuvrability characteristics of the boiler, we also studied the limitation of the maximum and minimum load by carrying out numerous computations and modelling. The maximum load of the power generating unit with the TPP-210A boiler is limited by the output of the induced-draft fan $\left(1050 \cdot 10^{3} \mathrm{~m}^{3} / \mathrm{h}\right)$ and by the temperature at the furnace outlet $\left(1100^{\circ} \mathrm{C}\right)$, which are the main conditions of the platen steam superheater slagging. The curves in Fig. 5 and Fig. 6 show that, when using direct firing, these limitations shift towards larger values by 5\% or $15 \mathrm{MW}$ for the $300 \mathrm{MW}$ power-generating unit.

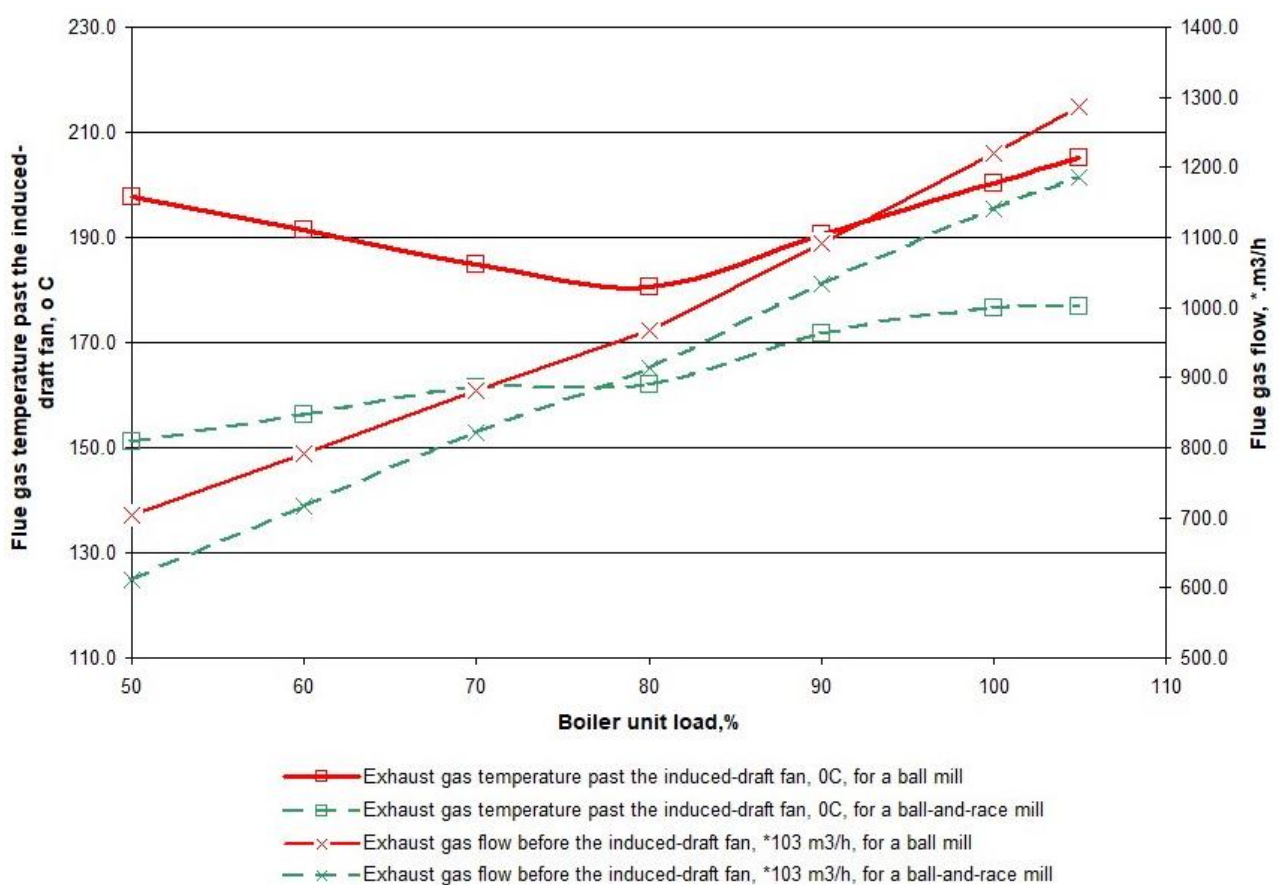

Fig. 5. Analysis of the change of the limitation indicators of the maximum load and gas temperature 
The minimum load is limited by the conditions of stable inflammation of pulverized coal for the unloaded boiler and conditions of the liquid slag output. The obtained graphic data (Fig. 6) show that due to zero feed of flue gas into the active combustion zone, increased temperature of the primary air, and absence of infiltrations into the pulverized coal system, the temperature at the active combustion zone outlet increased by about $100^{\circ} \mathrm{C}$. This ensured the conditions for steady liquid slag output at 50\% unloading of the boiler. A long operation of the TPP-210A boiler unit at such a low load is impossible, when using ball mills for the reasons discussed above. The extension of the unloading range is $10 \%$. As a result, the boiler manoeuvrability increased by $15 \%$ from the nominal load, or by $45 \mathrm{MW}$.

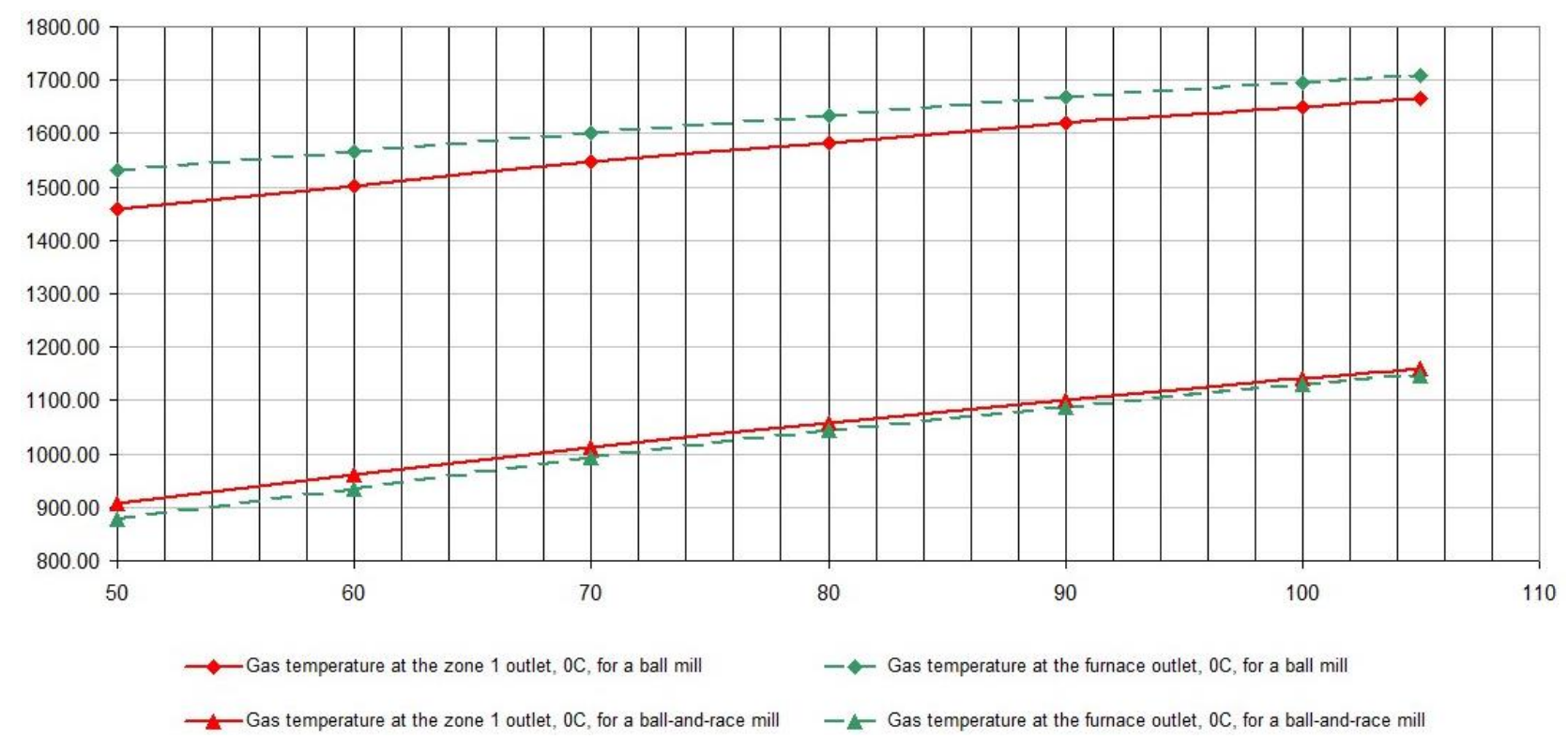

Fig. 6. Gas temperature in the furnace vs. unloading of the power-generating unit

Summarizing the change of the energy conversion efficiency of the power-generating unit resulting from the two factors (reduced heat loss with the exhaust gas and reduced heat consumption on electricity generation due to disabling the emergency injections), the annual economic effect was assessed to be 30.07 mil UAH.

In addition to the above-listed factors, the economic effect was also driven by the reduced electricity consumption on pulverizing the coal in the ball-and-race mill as compared to the ball mill at the level of 11.3 mil UAH per year (the reduction is $15 \mathrm{KW} / \mathrm{t}$ of pulverized coal); the cut in the cost of purchase of milling balls is $5.6 \mathrm{mil}$ UAH per year (consumption of metal for coal pulverization is reduced from $400 \mathrm{~g} / \mathrm{t}$ to $12 \mathrm{~g} / \mathrm{t}$ of pulverized coal). Therefore, for a $300 \mathrm{MW}$ power-generating unit at an average price of coal of $1650 \mathrm{UAH}$, the cumulative annual economic effect will amount to 46.97 mil UAH. So far, on the new market of electrical power there are no clear, comprehensible algorithms of defining the compensatory expenses on using the manoeuvrable capacities (ancillary services), which is why the economic effect from increasing the manoeuvrability range of the power-generating unit cannot be duly assessed.

\section{Conclusion}

The analysis of the technical condition and specificities of running coal-fired boilers showed that their modernization plans should be based on a comprehensive approach taking into consideration the improvement of economic indicators, manoeuvrability characteristics, fuel range extension and minimization of reconstruction costs.

The comparative analysis of the two pulverized coal systems, with ball mills and ball-and-race mills, proved that structural scheme with the ball-and-race mill offers a number of advantages, including the absence of a powder bin and reduced general flow of exhaust gas.

It was proved that the heat losses with the exhaust gas for the ball-and-race mill cases decrease and the gross energy conversion efficiency of the boiler unit grows by $2.47 \%$ on average. At the same time, the $0.48 \%$ heat loss reduction on the turbine is achieved by disabling the emergency injections to compensate for the overheating caused by the additional recirculation of the flue gas aimed at safe operation of the pulverized coal system with a ball mill. 
The study shows that owing to the zero feed of the flue gas into the active combustion zone, increased primary air temperature and absence of infiltrations into the pulverized coal system, the temperature at the active combustion zone outlet in the TPP-210A boiler unit with a ball-and-race mill increased by about $100^{\circ} \mathrm{C}$. This ensured the conditions for a steady output of liquid slag at a 50\% unloading. The extension of the unloading range for the scheme with a ball-and-race mill is $10 \%$. As a result, the boiler manoeuvrability increased by $15 \%$ from the nominal load, or by $45 \mathrm{MW}$.

It was assessed that for a $300 \mathrm{MW}$ power-generating unit at an average price of coal of $1650 \mathrm{UAH}$, the cumulative annual economic effect will amount to 46.97 mil UAH.

\title{
References
}

[1] Andrii Kapustyanskyi, Gennady Varlamov, ANALYSIS OF THE FUEL AND ENERGY COMPLEX OF UKRAINE // Scientific Journal of the Ternopil National Technical University 2016, No. 3 (83) ISSN 1727-7108. - pp. 144-153.

[2] Order No 62 of the Ministry of Ecology and Natural Resources of Ukraine dated 16 February 2018 on Changes to Order No 541 dated 22 October, 2008. (in Ukrainian)

[3] Law on the Principles of Monitoring, Reporting and Verification of Greenhouse Gas Emissions, dated 12/12/2019 N 377-IX. (in Ukrainian)

[4] A.A. Kapustyanskii, Study of Flame Combustion of Off-Design Binary Coal Blends in Steam Boilers // Thermal Engineering, 2017, Vol. 64, No. 7, pp. 534-541. - ISSN 0040-6015

[5] Cherniavskyi, N.B. Results of TPPs reconstruction in Ukraine in 2005-2015. // $11^{\text {th }}$ International Scientific and Practical Conference "Coal Thermal Power Industry: The Rehabilitation and Development”, Proceedings. - Kyiv: The Institute of Coal Energy Technologies of the NAS of Ukraine, 2015. - pp. 82-86. (in Russian)

[6] Cherniavskyi, N.B., Miroshnychenko, E.S., Provalov, A.Yu. An experience of converting TPP-210A boilers of 300 MW power-generating units of Trypilska TPP to gas coal // Electric Power Plants Journal. - 2020. - No7. - pp. 6-13. (in Russian)

[7] Varlamov, G.B., Kapustyanskyi, A.O. Effect of characteristics of non-standard solid fuel on the reliability and efficiency of boiler equipment operation // Power engineering: economy, technologies, ecology - No1 - 2018 - pp. 90-98. (in Ukrainian)

[8] Industry Guidance Document (GDK) 34.20.507-2003 Operation and maintenance of electrical power plants and networks. Regulations. K.: $\mathrm{OEP} \ll \mathrm{GRIFE} »-2003-597$ p. (in Ukrainian)

[9] RD 153-34.1-03.352-99 Explosion Hazard Regulations for Fuel Feed, Pulverized-Coal and Combustion Systems. (in Russian)

[10] Thermal Design of Boilers (normative method). - S.-Petersburg: JSC VTI, JSC NPO CKTI, 1998. - 259 p. (in Russian)

[11] RD 34.30.713-75 Typical Energy Characteristic of K-300-240 LMZ Turbine Generator. (in Russian)

\section{Покращення техніко-економічних показників енергоблоків теплових електростанцій шляхом відмови від рециркуляції димових газів}

\author{
Тарас Кравець $^{a}$, Свген Мірошниченко ${ }^{b}$, Андрій Капустянськийс \\ ${ }^{a}$ Національний університет "Львівська політехніка", вул. Степана Бандери, 12, м. Львів, 79013, Україна \\ ${ }^{b}$ Наиіональний університет харчових технологій, вул. Володимирська, 68, Київ, 01033, Украӥна \\ "ПрАТ "Техенерго", пр-т. Шевченка, 21, м. Львів, 79000, Україна
}

\section{Анотація}

Котлоагрегати енергоблоків теплових електричних станцій України потребують модернізації або заміни у короткостроковій перспективі, що $\epsilon$ важливим для енергетичної безпеки загальнодержавного рівня. Авторами визначено один 3 можливих варіантів покращення показників ефективності роботи вугільних котлоагрегатів та енергоблоків у цілому до значень, що перевищують проектні. Таким варіантом покращення $\epsilon$ відмова від технології застосування димових газів в якості сушильного та вентильованого агенту пилосистем та її заміна на пряме скидання газового потоку у паливню котла. Шляхом чисельних розрахунків досліджено зміну показників економічності та маневреності енергоблоків при заміні системи пилоприготування з кульовими барабанними млинами та сушінням вугілля димовими газами на схему 3 кільцево-кульовими млинами, що використовують як сушильно-вентильований агент гаряче повітря.

Ключові слова: маневреність; енергоблок; котел; пило система; вугілля; надлишок повітря; к.к.д. 